\title{
Mutual Optimism as a Cause of Conflict: Secret Alliances and Conflict Onset
}

\section{Citation}

Bas, Muhammet, and Robert Schub. 2016. "Mutual Optimism as a Cause of Conflict: Secret Alliances and Conflict Onset." International Studies Quarterly 60 (3) (March 14): 552-564. doi:10.1093/isq/sqw002.

\section{Published Version}

10.1093/isq/sqw002

\section{Permanent link}

http://nrs.harvard.edu/urn-3:HUL.InstRepos:33444605

\section{Terms of Use}

This article was downloaded from Harvard University's DASH repository, and is made available under the terms and conditions applicable to Other Posted Material, as set forth at http:// nrs.harvard.edu/urn-3:HUL.InstRepos:dash.current.terms-of-use\#LAA

\section{Share Your Story}

The Harvard community has made this article openly available.

Please share how this access benefits you. Submit a story.

Accessibility 


\title{
Mutual Optimism as a Cause of Conflict: Secret Alliances and Conflict Onset*
}

\author{
Muhammet A. Bas ${ }^{\dagger} \quad$ Robert Schub
}

Accepted for publication at International Studies Quarterly

\begin{abstract}
A prominent theory in International Relations posits that mutual optimism, due to two sides holding divergent estimates of their relative bargaining power, causes interstate conflict. This paper develops a theory of mutual optimism in which conflicting bargaining power estimates arise from asymmetric information about which, if any, third parties will join either side in a military dispute. We contend that secret alliances can generate mutual optimism which increases the probability of conflict. By exploiting secret alliances as a measurable source of private information, we provide the first systematic test of mutual optimism that directly assesses a state's secret capabilities. Optimism is present when a state's secret allies are more numerous or powerful than anticipated by opponents. Our empirical tests and numerous robustness checks strongly support the theoretical expectation. We conclude that mutual optimism is an empirically, as well as theoretically, important cause of interstate conflict.
\end{abstract}

${ }^{*}$ For helpful discussions and feedback, we are grateful to Songying Fang, Ashley Leeds, Anne Sartori, Beth Simmons, Dustin Tingley, Robert Trager, and Alex Weisiger. Additionally, we thank participants at the 2014 Annual Meeting of the Midwest Political Science Association, 2014 Annual Meeting of the Peace Science Society, and 2015 Empirical Implications of Bargaining Theory Conference at Princeton.

${ }^{\dagger}$ Department of Government, Harvard University. mbas@gov . harvard . edu

${ }^{\ddagger}$ Department of Government, Harvard University. Comments are welcome at rjschub@fas . harvard.edu. 
In the summer of 1990 before the Gulf War, representatives from Iraq and Kuwait approached their negotiations in Jeddah with divergent expectations regarding how the US would respond to conflict. Hearing from his Ambassador in Washington that there were "few risks of an American reaction in case of an intervention in Kuwait," Saddam Hussein believed the US would abstain from war (Freedman and Karsh, 1997, p. 59). In contrast, though wary of publicly expressing its close ties to the US, Kuwait expected US support if conflict erupted. The Emir of Kuwait sent his representative to Jeddah with the following message regarding two proposed Kuwaiti concessions: "Neither of these should happen. That is the view of our friends in Egypt, Washington, and London. Insist on your discussions. We are more powerful than they [Iraq] imagine" (Heikal, 1992, p. 181). These conflicting and optimistic estimates of the US response contributed to the breakdown in negotiations. ${ }^{1}$

Scholars frequently theorize that optimism akin to that observed in Jeddah is at the heart of international conflict. A state's uncertainty about opponent capabilities coupled with an opponent's incentives to misrepresent its strength during negotiations is one of the main reasons rational states fight costly wars (Morrow, 1989; Fearon, 1995; Powell, 1999; Slantchev, 2003; Slantchev and Tarar, 2011). Under such uncertainty, states form expectations about their prospects for winning a war and pursue peaceful settlements commensurate with their estimates of what can be secured through force. Bargaining may fail when states hold optimistic, and therefore conflicting, estimates about the prevailing power balance. ${ }^{2}$ According to Blainey (1988), "war is usually the outcome of a diplomatic crisis which cannot be solved because both sides have conflicting estimates of their bargaining power." Scholars have devoted significant attention to many sources of mutual optimism (Lebow, 1981; Fearon, 1995; Van Evera, 1999; Johnson, 2004) as well as the logical coherence of mutual optimism as a cause of war (Fey and Ramsay, 2007; Slantchev and Tarar,

\footnotetext{
${ }^{1}$ On pre-war expectations, see Freedman and Karsh (1997, ch. 3) and Khadduri and Ghareeb (1997, ch. 7).

${ }^{2}$ As discussed below, our strictly rationalist account defines mutual optimism as equivalent to the private information with incentives to misrepresent mechanism outlined in canonical bargaining models of war.
} 
2011; Fey and Ramsay, 2012). However, the empirical validity of the argument has eluded testing because of the inherent difficulty of identifying ex ante when a state is optimistic.

We advance the study of mutual optimism by (1) specifying how military support from allies can generate optimism and (2) conducting the first systematic test of whether mutual optimism actually causes conflict. Rationalist theories of war require asymmetric information, typically arising from new or improved military capabilities, in order to create optimism. We extend the underlying logic to encompass information asymmetries due to external, as opposed to internal, capabilities. Specifically, bargaining will fail due to mutual optimism when a state has private information that its allied support is greater than anticipated by its opponents. This theoretical extension highlights the importance of third party behavior as a source of private information.

For empirical testing, we exploit the presence of secret alliances as an ex ante measurable source of mutual optimism. Secret alliances produce information asymmetries by construction and consequently are an ideal indicator for the presence of optimism. Prior empirical efforts attempted to test the effects of mutual optimism in an indirect fashion by using variables that are assumed to proxy the amount of asymmetric information, such as dyadic balance of capabilities, which could possibly be proxies for other factors relevant for conflict (Reed, 2003; Slantchev, 2004). Our goal is to advance the empirical testing of optimism in a novel fashion by directly measuring the content of the asymmetric information - that is, by measuring a state's secret capabilities. In our approach, mutual optimism is present when these secret capabilities are greater than anticipated by opponents. Put differently, asymmetric information produces war in bargaining theory when a state believes an opponent is weak but it is actually strong, which constitutes mutual optimism in our account. Unlike past studies where opponent strength or "type" is unobserved, we systematically measure whether states are actually strong relative to opponent expectations.

Using an original measure of mutual optimism, we conduct extensive statistical tests and find strong support for the theory of mutual optimism as a cause of international conflict. This result is robust to multiple methods of accounting for potential confounding factors, including selection bias 
and rational expectations. We further illustrate the causal logic with a study of the 1908 Bosnian crisis. This case highlights the role of Austria-Hungary's secret alliance with Germany as a cause of the escalating tensions between Serbia and Austria-Hungary after the latter's annexation of Bosnia and Herzegovina. In sum, we provide evidence that beyond being theoretically prominent, mutual optimism is an empirically important cause of conflict.

This paper makes two additional contributions. First, it sheds light on secret alliances, which are generally overlooked by scholars despite once being a prominent feature of international politics. ${ }^{3}$ Second, focusing on external support as a source of private information highlights a recurring yet under theorized cause of war. ${ }^{4}$ Despite the lack of a formal alliance or absolute certainty for Kuwait regarding the US response, the Gulf War illustrates that problems posed by divergent expectations for joiner behavior are not confined to past eras in which secret alliances were more pervasive.

The paper proceeds as follows. The next section addresses the existing literature on the theoretical underpinnings and empirical support for mutual optimism as a cause of war. We then extend the theory to cover private information arising from external, as opposed internal, capabilities and specify the requisite conditions for the logical equivalence between the two to hold. The following section describes the research design and our measure of optimism stemming from secret alliances. In the ensuing section, we present results from statistical tests and address potential confounding factors. Next, we further illustrate the causal logic by analyzing the Bosnian Crisis of 1908. The final section concludes.

\footnotetext{
${ }^{3}$ Ritter (2004) offers the most thorough account of the causes and prevalence of secret alliances. On secrecy in democracies more generally, see Colaresi (2014).

${ }^{4}$ Van Evera (1999) is a notable exception.
} 


\section{Optimism and War: Theory and Evidence}

Mutual optimism resulting in disagreements about relative power is a prominent cause of war in the conflict literature. Van Evera (1999) argues that wars often arise due to false hopes about one's prospects for victory. He notes that "At least some false optimism about relative power preceded every major war since 1740, as well as many lesser and ancient wars" (Van Evera, 1999). Prominent examples include Athens-Sparta in 431 B.C.E, Britain against the American colonists during 1775-76, and many Arab leaders preceding the 1948 Arab-Israeli War. There are multiple potential sources for this optimism on the eve of conflict. Disagreements about power can arise due to emotional, perceptual, or cognitive biases. Johnson (2004) argues that positive illusions are the source of the overconfidence that exists before many wars. These illusions may have psychological and evolutionary roots that are embedded in human decision-making (see Jervis (1976); Kahneman and Renshon (2007) among others). Alternatively, the inherent complexity of international politics can limit estimation convergence. Bounded rationality causes individuals to reach divergent conclusions about the prevailing international conditions. In a related approach, Smith and Stam (2004) depart from standard rationalist models by allowing for heterogeneous priors such that states reach different estimates despite a lack of private information. Different theoretical perspectives — for instance, regarding the importance of army unit cohesion-generates heterogenous beliefs which in turn causes conflicting estimates about relative military power.

While noting the importance of these explanations, we focus on a different source of mutual optimism-a strictly rational one with common priors. Rationalist approaches argue that misperception and bounded rationality are unnecessary to explain disagreements about relative power and resolve (Wagner, 1994; Fearon, 1995; Powell, 1999). Instead, states are optimistic due to private information about their own capabilities coupled with incentives to misrepresent these factors. ${ }^{5}$ In

\footnotetext{
${ }^{5}$ Conflicting estimates of resolve can also produce optimism. However, we focus on private information about military capabilities given its closer match to the broader literature's conception of mutual optimism.
} 
most existing accounts, private information about capabilities stems from development of secret weapons_-such as US development of nuclear weapons during WWII_-or the changed quality of troops or strategy—such as the improved quality of Japanese military personnel before the RussoJapanese War.

Optimistic assessments alone are insufficient to undermine bargaining. Beyond having private information, states must be unable to eliminate their disagreement about relative power for rational actors to go to war. Many informal arguments about mutual optimism are ultimately incomplete because they do not address this issue (Fearon, 1995). The answer lies in a state's incentive to overstate its capabilities to secure a more favorable bargaining outcome, rendering such statements incredible. Alternatively, a state may misrepresent its strength due to incentives to hide capabilities or tactics to retain a military advantage. Given the inability to resolve the uncertainty, bargaining states strategically make a "risk-return tradeoff" that can leave a positive ex ante probability of war. States seek the reward of a more favorable bargaining outcome by making onerous demands that satisfy weaker opponents while running the risk of war with stronger opponents. War occurs when a state believes its opponent is weak when in fact it is strong. An implication of the model is that the probability of conflict is weakly increasing in opponent strength when private information is present.

There is some disagreement about whether the mechanism linking optimism to war is logically tenable. Fey and Ramsay (2007) argue that mutual optimism cannot be an explanation for war. If both states in a crisis appear willing to go to war, rational actors will infer that they either underestimated the opponent's strength or overestimated their own. They will avoid fighting that war and resolve the issue peacefully. Slantchev and Tarar (2011) note that this finding assumes states can always make an additional offer before war is irreversible, which may not hold in international crises. They show that provided either side can unilaterally initiate conflict, one party continuously revising offers cannot hold in equilibrium because there is no information revelation and the dissatisfied state prefers fighting over endless delay. More substantively, delay is costly for 
the state that is dissatisfied with the status quo. Beyond the costs of suffering through the status quo, costs could arise from domestic considerations, such as audience costs (Fearon, 1994; Weeks, 2008), or reputational considerations for future interactions (Sartori, 2002). Without the assumed permissiveness of endlessly revisable offers in the bargaining environment, mutual optimism is a logically coherent explanation for war.

A definitional distinction is central to the concept of mutual optimism. In one account, onesided private information where state $A$ is uncertain about $B$ 's capabilities while $B$ knows $A$ 's capabilities can produce mutual optimism (Slantchev and Tarar, 2011). Mutual optimism exists in this framework when $A$ believes $B$ is a weaker type but $B$ is actually a stronger type. As noted in Fey and Ramsay (2012), this is not an immediately intuitive definition of mutual optimism because $B$ knows the balance of capabilities and bargains accordingly. A stricter definition of mutual optimism might involve two-sided private information where each side believes the other is weak when they are in fact strong. Fey and Ramsay (2012) demonstrate that two-sided optimism neither ensures war will occur nor is necessary for war to occur in equilibrium. Though cognizant of this distinction, we stipulate that one-sided uncertainty is sufficient to generate conflicting estimates of relative strength, which underpins the causal mechanism that links mutual optimism to conflict. ${ }^{6}$ In our account mutual optimism exists if on the eve of war the two sides' private estimates of the probabilities of victory sum to greater than one, regardless of whether private information is one or two-sided.

Despite its theoretical prominence, there is little empirical testing of the mutual optimism theory of war. It is challenging to consistently specify ex ante when a state is optimistic. Risking tautology, optimism is often inferred ex post from the fact that war occurred. Studies of wars arising from optimism are thus helpful for highlighting the causal logic of mutual optimism (Lebow,

\footnotetext{
${ }^{6}$ That being said, since our empirical framework captures both one-sided and two-sided optimism, it can also be tailored to test strictly two-sided optimism as described by Fey and Ramsay (2012).
} 
1981; Blainey, 1988; Van Evera, 1999), but insufficient for drawing inferences as they select observations based on the dependent variable's value.

An alternative approach is to measure uncertainty rather than optimism. If the risk-reward tradeoff increases the probability of war, then greater uncertainty should associate with more conflict. For instance, Reed (2003) assumes power parity can proxy for asymmetric information and finds strong support linking uncertainty to conflict. Slantchev (2004) similarly uses military parity as a measure of uncertainty when testing explanations of war duration. ${ }^{7}$ We depart from this framework. Extant tests offer valuable results consistent with mutual optimism theory, but are indirect tests as they do no specify exactly when a state faces a strong opponent. Moreover, parity could be a poor proxy for asymmetric information as it captures other factors, such as uncertainty about a conflict's outcome, that can affect conflict onset. Rather than gauge when a state is more uncertain whether its enemy is strong or weak, we aim to directly measure enemy strength.

The results also have implications for the alliance literature given our use of secret alliances as a source of private information. Whether alliances deter aggression is a recurring question. Alliances can credibly signal a commitment to defend proteges and thus deter attacks (Smith, 1995; Fearon, 1997; Morrow, 2000), though secret alliances lack this feature. A countervailing force is that a pledge of support may induce moral hazard, emboldening states and consequently entrapping or dragging allies into conflict (Snyder, 1984). Secret alliances pose a risk of moral hazard, particularly as various pacifying attributes (see Yuen (2009); Benson, Meirowitz and Ramsay (2014)) are unavailable due to the opponent's lack of knowledge about the alliance. However, a secret ally's recommendation for settlement can have a restraining effect that diminishes the risk of moral hazard (Fang, Johnson and Leeds, 2014). Efforts to empirically assess the effect of alliances on conflict onset highlight the need to differentiate between various forms of alliances-such as offensive versus defensive (Leeds, 2003b; Benson, 2011). Our results contribute to such efforts by demonstrating a consistent positive relationship between secret alliances and conflict onset.

\footnotetext{
${ }^{7}$ Others have proposed alternative proxies for uncertainty (Wolford, 2007; Bas, 2012; Rider, 2013).
} 


\section{Theorizing Mutual Optimism and Secret Alliances}

Disagreement about relative strength due to private information can have a variety of sources. As noted earlier, most rationalist accounts attribute private information to domestic factors such as the quality of a state's own military forces (in terms of personnel, technology, tactics or logistics). However, private information about outside help from third parties in a conflict can also cause relative power disagreements. Noting this possibility, we extend the logic of asymmetric information and mutual optimism to encompass instances where states disagree about third party involvement in conflict due to private information. More specifically, we theorize that secret alliances can produce mutual optimism.

How does the existence of secret alliances cause asymmetric information about capabilities, and ultimately, mutual optimism and war? Akin to a state having private information about its military capabilities, a state has private information about whether it has secret allies. Awareness that secret alliances are possible generates uncertainty about an opponent's capabilities and warfighting strength. For instance, if state $A$ is unsure whether state $B$ has secret allies, $A$ will develop a prior expectation about $B$ 's likely secret allies and make the standard risk-return tradeoff in bargaining. Based on these prior expectations about the opponent's potential allies, the uncertain state could make offers that satisfy the weaker types of the opponent, while risking war in cases in which the opponent has more or stronger secret allies. Analogously to the typical framework, mutual optimism occurs when the opponent state turns out to be stronger than anticipated due to its secret allies. Under these conditions, bargaining breaks down and conflict ensues.

Why construct a theory based on secret alliances rather than private information about domestic capabilities? First, as discussed below, secret alliances were a widespread feature of international politics for over a century during the post-Napoleonic era. Yet, they are barely addressed in the literature. The sheer prevalence of secret alliances merits their investigation. Second, unknown allies can dramatically change the balance of capabilities, particularly when the ally is a major power. 
The magnitude of change to the power balance due to secret domestic capabilities, other than nuclear weapons, is likely smaller. Third, while private information about domestic capabilities is a prominent theoretical cause of war, it has eluded systematic empirical testing. The difficulty of specifying ex ante whether a state's secret capabilities make it a weak or strong type is an immediate impediment to rigorous analysis. Secret alliances do not suffer from this complication, enabling the first systematic test of mutual optimism as a cause of war. Using the Alliance Treaty Obligations and Provisions (ATOP) data set (Leeds et al., 2002), we can easily determine a state's secret capabilities. Those states with no or limited secret allies are weak types while those with numerous or powerful secret allies are strong types. Secret alliances allow for an ex ante coding of mutual optimism and a test of its effects. ${ }^{8}$

Secret alliances were once a fixture of international politics. Between 1815 and 1956, states formed 36 secret alliances entailing an offensive or defensive pact between the signatories. ${ }^{9}$ This represents over $20 \%$ of the offensive or defensive alliances formed during this temporal span. Secret alliances had an average duration of nearly 10 years with a range from less than a year to 51 years. These averaged 2.3 members per alliance with the largest having five member states. In the ATOP data, there have been no secret alliances since the 1956 UK-France-Israel pact that preceded the Suez Crisis. Whether the dearth of secret alliances in recent decades is attributable to their ongoing secrecy or a change in their attractiveness as tools of diplomacy is a question we leave open for future research. The left panel of Figure 1 plots the frequency of secret alliance formation across decades.

\footnotetext{
${ }^{8}$ We do not claim that external capabilities are a more important or frequent source of private information than internal capabilities. Rather, we claim that the two sources of a private information have equivalent theoretical implications for the likelihood of conflict. The ability to reliably measure secret external power sources allows for a test of those implications.

${ }^{9}$ Descriptive statistics are based on ATOP data where only entirely secret alliances, as opposed to those with secret clauses, are included.
} 
Though widespread and convenient for empirical testing, are secret alliances and domestic capabilities actually analogous sources of private information? That is, does testing mutual optimism arising from secret alliances capture the theoretical question of interest? To address this concern, consider three salient features of the standard model specifying how domestic capabilities induce mutual optimism. First, the capabilities must be private information. Secret alliances fulfill this criteria as they are private by construction. Beyond intent, there is evidence that secret alliances did remain private information even years beyond formal signing. Opponents were unaware of portions of the Triple Alliance, originally signed in 1882, until the end of WWI. The Reinsurance Treaty, a neutrality and consultation pact, remained a secret from its intended target, Austria-Hungary, until years after its expiration (Ritter, 2004, p. 40). Note that a possible lack of secrecy in practice in some cases, which eliminates the source of private information and divergent estimates, would bias against finding the anticipated relationship between secret alliances and conflict onset.

Second, there must be incentives to misrepresent one's own strength. Secret alliances create such incentives by their very secrecy. Beyond secrecy by construction, there are multiple reasons states may have a preference not to reveal an alliance. Secrecy allows diplomats to avoid a negative domestic or international response. Diplomats may prefer to hide cooperation with a partner that is scorned by the domestic population or existing partners. Kuwait's wariness about revealing the depth of its ties to the US during the buildup to the Gulf War is an example of such reasoning (Freedman and Karsh, 1997, p. 63). Another rationale, consistent with the logic described in Slantchev (2010), is that tactical advantages gained on the battlefield through feigning weakness by keeping alliances secret may be more attractive than the potential bargaining gains made by signaling strength through alliance revelation. Battlefield advantages can accrue from a secret ally opening a second front against an unsuspecting enemy, though this tactic is potentially limited to secret offensive alliances. More generally, alliance treaties often specify military commitments and plans stipulating how members will respond in conflict. Keeping the plan secret can improve an alliance's military prospects. 
Due to these incentives to underreport capabilities, a state will not simply reveal an alliance on the eve of conflict in order to facilitate a peaceful bargain. The benefits of secrecy, such as maintaining a tactical advantage from a surprise attack on a second front, outweigh the costs associated with risking conflict. ${ }^{10}$

Multiple mechanisms create incentives for an actor to underreport or misrepresent its strength, which is a necessary condition for secret alliances to be a source of mutual optimism. Because we are concerned with the consequences of secret alliances, our goal is not to adjudicate between the posited mechanisms. Rather, the causes are only theoretically important insofar as they illustrate the logical equivalence between external and internal capabilities as sources of mutual optimism or they introduce bias in the estimates of their consequences. On this latter point, consider scenarios where secret alliances grant states a military advantage through the element of surprise. This explanation is problematic for testing whether mutual optimism increases the risk of conflict. Specifically, the intention to attack an enemy will be a common cause of both secret alliance formation and conflict onset, which biases results upward if we cannot control for intention to attack. We extensively address this prospect of selection effects in the results discussion.

A third condition required for the mutual optimism argument to hold is that a state with private information about its capabilities must anticipate being able to actually use those capabilities. This condition is immaterial for domestic military capabilities because a state can marshall its resources as it sees fit. For secret alliances, this condition specifies that states believe secret alliances are credible. The literature argues that alliances are costly signals which convey the credibility of the formalized commitment (Morrow, 2000). The signaling costs arise from the (1) logistical and operational complexities of crafting and maintaining an alliance, (2) domestic and international

\footnotetext{
${ }^{10}$ Such revelations may face additional complications as an enemy may not believe the revelation because the "revealing" state also has incentives to overreport its strength to secure more advantageous bargains. However, this cheap talk mechanism, which is a central in most accounts detailing how private information can cause war, may not apply to secret alliances if states can credibly show opponents the actual alliance document together with a secret confirmation from the ally.
} 
audience costs incurred, or (3) revelation of strategic vulnerabilities to alliance partners. Beyond multiple theoretical underpinnings, data indicates alliances are reliable as states fulfill their specific alliance commitments in $75 \%$ to $80 \%$ of cases (Leeds, Long and Mitchell, 2000; Leeds, 2003a). ${ }^{11}$

Empirically, states honor their secret alliance commitments $74 \%$ of the time. ${ }^{12}$ Theoretically, secret alliance credibility is partly diminished by the lack of immediate audience costs beyond the constituent members. However, the other costly signaling components of alliances, such as the diplomatic costs of crafting the agreement, are still present and provide reasons for a state to believe its secret ally's commitment is credible. Additionally, Yarhi-Milo (2013) illustrates how secrecy can be a form of tying hands as a scorned partner can threaten to reveal the secret agreement. Consequently, if the conditions for alliance obligations are met, states will suffer the costs of alliance revelation regardless of whether they fulfill their obligations. Leverage from this threat to go public gives secret commitments an alternative signaling mechanism, highlighting ex post rather than ex ante treaty costs (Simmons, 2010). There is evidence that states took their secret commitments seriously. Consider the 1887 Reinsurance Treaty between Russia and Germany. After three years, Germany opted not to renew the alliance when Russia expressed interest in renewing it. If secret alliances were cheap and not credible, Germany would have renewed the agreement to benefit from Russian non-aggression even if Germany did not intend to fulfill its own

\footnotetext{
${ }^{11}$ Failure to uphold commitments occurs when reneging costs are lower, which arises when constituent members are less democratic, are major powers, or experience significant changes in military capabilities or domestic institutions (Leeds, 2003a). Generally, states are more likely to abrogate alliances if they are non-democratic (Leeds, Mattes and Vogel, 2009), there is a change in the balance of power, change in the value of the alliance itself, a new alliance partner, or change in domestic political institutions (Leeds and Savun, 2007). See Gartzke and Gleditsch (2004) for an opposing result on democratic ally reliability, Langlois (2012) for a formal account of how ally reliability varies depending on whether the enemy is the initiating or targeted state in a dispute, and Mattes (2012) on the when states incorporate reliability-enhancing measures into alliance treaties to guard against defection and abrogation.

${ }^{12}$ We calculate the fulfillment rate using data from Leeds (2003a) and ATOP codings. This figure is most comparable to the $80 \%$ reliability figure for all alliances, public and secret, from Leeds (2003a).
} 
commitments. Germany allowing the treaty to lapse is consistent with the contention that secret alliances entail costs and credible commitments.

Beyond signaling, there are reasons for states to believe they will benefit from an ally's capabilities. Benefits may accrue even if the alliance does not explicitly target the relevant opponent in the text of the formal alliance. An alliance could signal a general similarity of security preferences between two states. As a result, allies may support each other when facing common threats beyond those noted in the alliance treaty. Alternatively, the security afforded by a secret alliance may allow states to marshall resources away from secure areas and toward conflictual areas. For example, if $A$ knows its secret ally will assist with any threats from the west, $A$ can move more of its forces to the east. $A$ 's eastern neighbor, unaware of $A$ 's ability to bring additional forces to a potential conflict would underestimate $A$ 's power. That is, mutual optimism can arise because a secret ally allows a state to shift its forces in ways than an opponent cannot anticipate. States can benefit from allies through other means. Consider the 1911 Italo-Turkish War. After receiving Italy's ultimatum demanding territorial concessions in Ottoman North Africa, the Ottomans appealed to the other major powers to intervene and thwart the Italian plans (Childs, 1990, ch. 3). These overtures were ignored as Italy had already secured European backing for its military objectives, most notably through the 1891 additions to the Triple Alliance. ${ }^{13}$ Moreover, if an ally's presence is secret, an enemy cannot modulate its demands to deter that ally's conflict entry (Werner, 2000).

In sum, the inherently private nature of secret alliances, resulting incentives to misrepresent capabilities, and expected credibility of the commitment make secret alliances an appropriate source of private information to use for testing mutual optimism's effect on conflict proclivity. Consequently, the implications of standard bargaining models with asymmetric information are applicable in this context. Given that an opponent has private information about its strength with incentives to misrepresent, the probability of conflict is weakly increasing in opponent strength. Our central

\footnotetext{
${ }^{13}$ See Childs (1990, p. 3) on the 1891 amendments to the Triple Alliance pertaining to Cyrenaica and Tripolitania.
} 
hypothesis follows: mutual optimism, due to a state underestimating an opponent's secret allies, increases the probability of an international conflict.

\section{Research Design}

Mutual optimism exists, in the sense described above, when at least one state optimizes its bargaining behavior conditional on a belief that the opponent is weaker than it actually is. A measure of mutual optimism must identify instances where a state underestimates an opponent's capabilities and thus the two sides disagree on the prevailing power balance. The first step in constructing a measure of mutual optimism is to calculate the dyadic balance of power as each state perceives it. We specify this process as follows. Each state within the dyad calculates its own capabilities, including those of its key allies, and the capabilities of the opponent state in the dyad, including the opponent's allies. The states then respectively calculate their probabilities of victory in a military conflict based on the estimates of each side's capabilities. When there are secret alliances, the sum of estimated victory probabilities will exceed one. By measuring the content of each state's private information — a state's secret allies-we construct a variable capturing the presence of mutual optimism.

To start, we calculate each state's estimates of its own and its opponent's capabilities. Following much of the conflict literature, we employ CINC scores as an indicator for each state's latent military capabilities (Singer, Bremer and Stuckey, 1972). ${ }^{14}$ We use the Alliance Treaty Obligations and Provisions (ATOP) data set to gauge how a state will assess which military capabilities to add to its own and which to add to its opponent's capabilities (Leeds et al., 2002). ATOP data

\footnotetext{
${ }^{14} \mathrm{CINC}$ scores are an admittedly crude composite measure that reflects a state's population totals, industrial output, and some of its military indicators while ignoring others, such as the size of a state's nuclear arsenal. However, it is widely employed and arguably the best available metric that has sufficient spatial and temporal coverage for our analysis.
} 
is ideal for this purpose because it codes whether alliances are offensive, defensive, neutrality, or nonaggression pacts as well as indicating whether any, or all, alliance provisions are secret.

Each side calculates its own total military capabilities as follows. Let $A$ be the state making the assessment, $B$ is $A$ 's opponent within the dyad, and $C$ is a third party. $A$ 's calculation of its total capabilities will include its own CINC score as well as that of $C$ if $A$ and $C$ share a public offensive or defensive or a secret offensive or defensive alliance provided that $C$ does not have any public alliance with $B$, including neutrality pacts. Note that $C$ is not a single state but rather stands for all states outside the dyad in question. ${ }^{15}$

There are three important assumptions underpinning this calculation. First, $A$ assumes its allies will provide military support in a conflict. As discussed earlier, there are numerous reasons to expect that alliance commitments are met in most cases. ${ }^{16}$

A second assumption is that $A$ includes a secret ally's capabilities regardless of the alliance being offensive or defensive. The logic for including offensive allies is immediate; the logic for defensive allies is two-fold. First, a state that receives threats from opponents demanding concessions will resist making concessions that are not commensurate to its own estimated bargaining power. This estimate will include secret defensive allies if the opponent's threat is an ultimatum implying an attack if the concessions are not granted. Second, including defensive alliances provides a tougher test of the theory. Secret offensive alliances are more susceptible to the selection concern of states signing secret agreements when already planning to initiate conflict. A state with intentions to attack is unlikely to seek defensive allies.

Third, the main specification assumes $A$ anticipates its secret ally's support even if the alliance does not explicitly target $B$. As noted above, multiple mechanisms allow $A$ to benefit from its

\footnotetext{
${ }^{15} \mathrm{We}$ code alliances as public if any articles are public and secret only if all articles are secret.

${ }^{16}$ Sobek and Clare (2013) offer an alternative framework by calculating a measure of external power that accounts for reneging by using observed joining proclivity of third parties to proxy for alliance reliability. This method is inappropriate in our study as the theory being tested specifies that each side knows its own capabilities with certainty.
} 
ally's capabilities even when they are not formally directed at $B$. Nonetheless, Leeds, Long and Mitchell (2000) highlights the importance of focusing on the specific commitments made in an alliance. Accordingly, we present robustness tests in which $A$ only anticipates ally support when $B$ is the specific target of the formal alliance. Results are substantively and statistically similar using a target specific measure.

In addition to calculating its own capabilities, $A$ must estimate those of $B$ and its allies. $A$ 's estimate will include $B$ 's own CINC score as well as that of $C$ if $B$ and $C$ share a public offensive or defensive alliance, provided that $A$ and $C$ have no agreement of any form. Importantly, $A$ 's estimate will understate $B$ 's actual aggregate capabilities if $B$ and $C$ share a secret alliance. Finally, $A$ calculates the sum of unaccounted for capabilities which includes $C$ if $C$ has no agreement with $A$ and no public alliance with $B$. This pool of unattributed capabilities will be essential in the next section. The supplementary files contain a summary of the capability calculations.

The next step is to calculate each side's estimated probability of victory. When these estimates sum to greater than one, the states are mutually optimistic. To model victory probabilities we adopt a standard ratio form contest success function in which a state's share of total capabilities represents its probability of victory. Let $p_{i}$ equal the probability of state $i$ 's victory as perceived by $i$, which is a function of each state's publicly known capabilities including its domestic capabilities and those of its public allies, $c_{i}^{p}$, and a state's secret capabilities stemming from secret alliances, $c_{i}^{s}$. Thus, $A$ and $B$ estimate their respective chances of victory as

$$
p_{A}=\frac{c_{A}^{p}+c_{A}^{s}}{c_{A}^{p}+c_{A}^{s}+c_{B}^{p}} ; p_{B}=\frac{c_{B}^{p}+c_{B}^{s}}{c_{B}^{p}+c_{B}^{s}+c_{A}^{p}}
$$

The sum of $p_{A}$ and $p_{B}$ provides a measure for mutual optimism. In this specification, the two expected probabilities of victory will equal one in the absence of secret allies. When there are secret allies, the sum will exceed one and there is mutual optimism. 


\section{Accounting for Rational Expectations}

While the above measure provides an initial proxy for mutual optimism, it neglects the rational expectations states will have about the possibility an opponent has secret allies. Aware that secret alliances can exist, a state ought to incorporate the possibility that some of the unaccounted for third parties are actually secret allies with the opponent. Incorporating a prior expectation for secret alliances into the estimated probability of victory restricts the set of instances where there is mutual optimism to only those cases where there are more secret alliances, or more powerful secret allies, than anticipated. That is, accounting for rational expectations insures that the mutual optimism measure only exceeds one when at least one state in a dyad is stronger than an opponent believes it to be.

Returning to the earlier framework, we incorporate the possibility of secret allies into $p_{i}$ by specifying a prior expectation for the share of unaccounted for capabilities that are actually secretly aligned with the opponent. Let $c_{i}^{u}$ represent the sum of unaccounted for capabilities as perceived by state $i$ and let $\phi$ indicate the prior. ${ }^{17}$ Incorporating these parameters produces

$$
p_{A}=\frac{c_{A}^{p}+c_{A}^{s}}{c_{A}^{p}+c_{A}^{s}+c_{B}^{p}+\phi c_{A}^{u}} ; p_{B}=\frac{c_{B}^{p}+c_{B}^{s}}{c_{B}^{p}+c_{B}^{s}+c_{A}^{p}+\phi c_{B}^{u}} .
$$

What constitutes a good prior expectation $(\phi)$ for an opponent's secret alliances? That is, what share of the states that have no public alliance with either dyadic member should be estimated to be secret allies with an opponent? In the measure described earlier, the prior is implicitly set at zero. This is likely inappropriate. However, specifying a prior ex ante is difficult because the extent of secret alliances is rarely evident to any single state. A state will know of its own secret alliances and potentially those of others that are revealed by conflicts that involved members of a secret alliance. Even this latter case may not make the alliance evident because states may join conflicts without being bound to by formal agreements. Beyond these scenarios, secret alliances

\footnotetext{
${ }^{17}$ The value of $c_{i}^{u}$ will differ for $A$ and $B$ when there is a secret alliance.
} 
are probably unknown to states that are not party to the agreement. The central dilemma for estimating a prior is that while states know secret alliances exist, their pervasiveness is masked. Moreover, rational actors will know this information is masked.

For a baseline, we use the observed rate of secretly aligned capabilities in the data set as the prior each state uses for calculating an opponent's strength. Doing so balances two considerations. First, as discussed, states are unaware of most secret alliances in which case the observed rate in the data will be too high. Second, states know they do not know of all secret alliances and ought to use a prior higher than the rate they witness. These countervailing considerations make the observed rate of secret alignment a plausible baseline for the prior. For an alternate approach, we estimate a specification that models the prior as a function of the regressors. This allows priors to vary across observations. We find similar substantive results with this modeling approach, hence we opt to focus on simpler and less demanding specifications throughout the analysis.

When looking across all politically relevant dyads during the temporal period in which secret alliances were prevalent (1816-1923), an average of 2.8\% of unaccounted for capabilities were secretly aligned with one state in the dyad. ${ }^{18}$ Using these priors and summing the resulting estimated probabilities of victory within the dyad provides an alternative specification for Mutual Optimism. The right panel of Figure 1 shows a density plot for this measure where $8.1 \%$ of observations have summed probabilities of victory greater than one. In the empirical tests we check the sensitivity of our results to alternative priors and find substantively similar results for a range of plausible values on either side of the observed rate. Note that the sum of the probabilities of winning can be less than one if an opponent has fewer or less capable secret allies than anticipated-that is, the actual strength of secret allies is less than the prior. Under this condition a state's estimate about its share of relative capabilities proves to be pessimistic.

\footnotetext{
${ }^{18}$ Politically relevant dyads are those which contain at least one major power or where the states are contiguous or separated by less than 400 miles of water.
} 

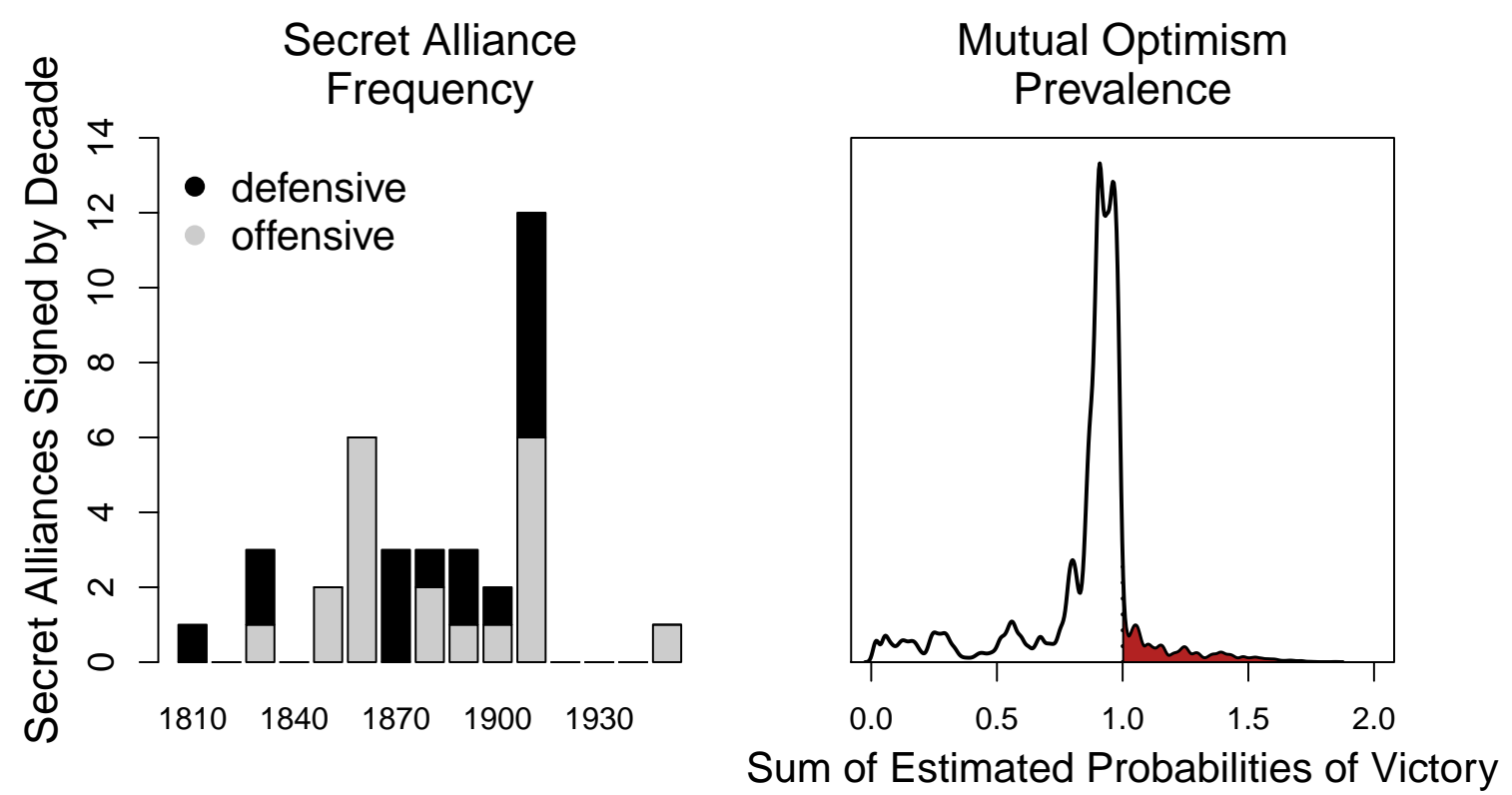

Figure 1: Secret alliance and mutual optimism frequency in the data. Left panel shows the distribution of secret alliance formation by decade, distinguishing between offensive and defensive alliances. Right panel is a density plot of the Mutual Optimism variable when using a prior expectation rate equal to the observed rate of secret alignment in the data. Red fill indicates portion of observations where mutual optimism is present.

\section{Unit of Analysis and Variable Specification}

The unit of analysis for empirical testing is the non-directed dyad year. A non-directed dyad approach is appropriate because either state could initiate a dispute when the two parties cannot reach an acceptable bargain due to conflicting estimates of the power balance. We use politically relevant dyads, in which the states are contiguous or at least one is a major power, as the main specification for all analyses. Observations span a temporal range from 1816 to 1923 . Excluding dyads after 1923 is justified because there was only one recorded secret alliance signed in this period. The apparent disappearance of secret alliances may be due to the ongoing secrecy of such deals or because many condemned the future practice of secret diplomacy after WWI. Regardless of the motives, the fundamental change in secret alliance prevalence limits the scope of observations in which they are a substantively important potential source of mutual optimism. Moreover, the 
temporal bounds are justified on methodological grounds. Including observations for which some values of the explanatory variable are unrealizable — such as the presence of mutual optimism due to secret alliances after 1923 - violates the positivity assumption of empirical analysis (Hernan and Robins, 2006). Accordingly, we exclude these cases from the sample. ${ }^{19}$

Following much of the international conflict literature, Militarized Interstate Dispute (MID) onset is the binary outcome variable for all analyses (Ghosn, Palmer and Bremer, 2004). Disputes can entail threats to use force, force displays, or the actual use of force up to and including war. All of these are indicative of the bargaining difficulties expected as a result of mutual optimism. The outcome variable equals one if it is the initial year of a dispute and the states in the dyad are the originating parties in that dispute. Restricting the outcome variable to only instances with the actual use of force produces equivalent results, as reported in the supplementary files. The Mutual Optimism measure described earlier is the explanatory variable. We operationalize it as both a dichotomous - equal to one if the sum of estimated probabilities of victory exceeds one — and a continuous variable equal to the sum of estimated probabilities. Additionally, the specifications include Mutual Optimism calculated both with and without including a prior expectation of the opponent having secret allies.

We include control variables for a standard array of confounding factors identified in prior conflict studies. Relative Capabilities measures the weaker state's share of total dyadic capabilities and thus spans from zero to 0.5 , with the latter representing power parity. This measure uses CINC scores but unlike Mutual Optimism it excludes external capabilities from states outside the dyad. Prior work finds dyads near parity are particularly conflict prone (Reed, 2003). Contiguity is a dichotomous indicator for whether the states in a dyad share a border or are separated by less than 400 miles of water. Territorial proximity is consistently associated with an increase in the probability of conflict (Bennett and Stam, 2004; Starr and Thomas, 2005). The vast democratic peace

\footnotetext{
${ }^{19}$ The substantive results are robust to using earlier post-WWI cutpoints, but we choose to use 1923 to maximize sample size while maintaining the positivity assumption.
} 
literature suggests democratic states are unlikely to fight one another (Oneal, Russett and Berbaum, 2003). To account for this we control for Joint Democracy which is a binary variable equal to one if both states have Polity IV scores greater than six (Marshall and Jaggers, 2002). States that share an alliance are less likely to engage in disputes. Accordingly, we include a binary Alliance variable that indicates whether states have any formal alliance (Gibler and Sarkees, 2002). Finally, to account for temporal dependence in the data we include polynomial terms that measure the duration since the prior MID within a dyad-Peace Years, Peace Years ${ }^{2}$, and Peace Years ${ }^{3}$ (Carter and Signorino, 2010). Summary statistics for all variables are provided in the supplementary files.

\section{Results}

Due to the dichotomous outcome variable, we estimate all models with logistic regression with standard errors clustered on the dyad. Across specifications we find consistent support for the mutual optimism hypothesis. Table 1 reports results for four specifications with the first two using Mutual Optimism as constructed without a prior expectation. When modeling the presence of mutual optimism with a continuous measure, there is a substantively and statistically significant relationship between mutual optimism whether ignoring (Model 1) or incorporating (Model 3) prior expectations of an opponent having secret allies. An increase in the sum of the estimated probabilities of victory increases the probability of a militarized dispute. Using a dichotomous indicator to measure mutual optimism with or without a prior expectation (Models 4 and 2 respectively) produces equally strong results. Control variables point in the expected direction across specifications, though Joint Democracy is not significant in this temporal span.

What are the substantive implications of these results and how sensitive are they to the prior expectation of an opponent having secret allies? Figure 2 addresses both of these questions. First, consider the substantive effect of shifting the dichotomous mutual optimism measure from zero to one. We use Clarify to simulate quantities of interest based on the results in Model 4 (King, Tomz and Wittenberg, 2000). With all control variables set to the median values and Mutual Optimism 
Table 1: Mutual Optimism and Conflict

\begin{tabular}{|c|c|c|c|c|}
\hline & \multicolumn{2}{|c|}{ No Prior } & \multicolumn{2}{|c|}{ Prior } \\
\hline & (1) & $(2)$ & $(3)$ & (4) \\
\hline & Continuous & Dichotomous & Continuous & Dichotomous \\
\hline \multirow[t]{2}{*}{ Mutual Optimism } & $1.13 * * *$ & $0.46^{* * *}$ & $0.38^{*}$ & $0.49 * * *$ \\
\hline & $(0.33)$ & $(0.12)$ & $(0.20)$ & $(0.14)$ \\
\hline \multirow[t]{2}{*}{ Relative Capabilities } & $2.18 * * *$ & $2.35 * * *$ & $2.41 * * *$ & $1.99 * * *$ \\
\hline & $(0.54)$ & $(0.52)$ & $(0.52)$ & $(0.54)$ \\
\hline \multirow[t]{2}{*}{ Contiguity } & $0.84 * * *$ & $0.90 * * *$ & $0.92 * * *$ & $0.86 * * *$ \\
\hline & $(0.18)$ & $(0.18)$ & $(0.18)$ & $(0.18)$ \\
\hline \multirow[t]{2}{*}{ Joint Democracy } & -0.06 & -0.15 & -0.07 & -0.09 \\
\hline & $(0.26)$ & $(0.24)$ & $(0.25)$ & $(0.25)$ \\
\hline \multirow[t]{2}{*}{ Alliance } & $-0.81 * * *$ & $-0.79 * * *$ & $-0.80 * * *$ & $-0.79 * * *$ \\
\hline & $(0.22)$ & $(0.22)$ & $(0.22)$ & $(0.22)$ \\
\hline \multirow[t]{2}{*}{ Peace Years } & $-0.14 * * *$ & $-0.13 * * *$ & $-0.14 * * *$ & $-0.13 * * *$ \\
\hline & $(0.01)$ & $(0.01)$ & $(0.01)$ & $(0.01)$ \\
\hline \multirow[t]{2}{*}{ Constant } & $-4.46 * * *$ & $-3.50 * * *$ & $-3.67 * * *$ & $-3.32 * * *$ \\
\hline & $(0.38)$ & $(0.18)$ & $(0.24)$ & $(0.16)$ \\
\hline$N$ & 24,886 & 24,886 & 24,886 & 24,886 \\
\hline
\end{tabular}

Notes: Logistic regression with non-directed politically relevant dyad year as the unit of analysis. Standard errors in parentheses are clustered on the dyad. Results for higher order Peace Years are not shown. 
fixed at zero, there is a $2.7 \%$ predicted probability of conflict. ${ }^{20}$ Shifting Mutual Optimism to one increases the probability of conflict by $1.6 \%$ points, with $90 \%$ confidence bounds spanning from $0.8 \%$ to $2.5 \%$ points. That is, when secret allies are more numerous or more powerful than anticipated, there is a roughly $60 \%$ relative increase in conflict likelihood. The vertical red line in Figure 2 show this effect.

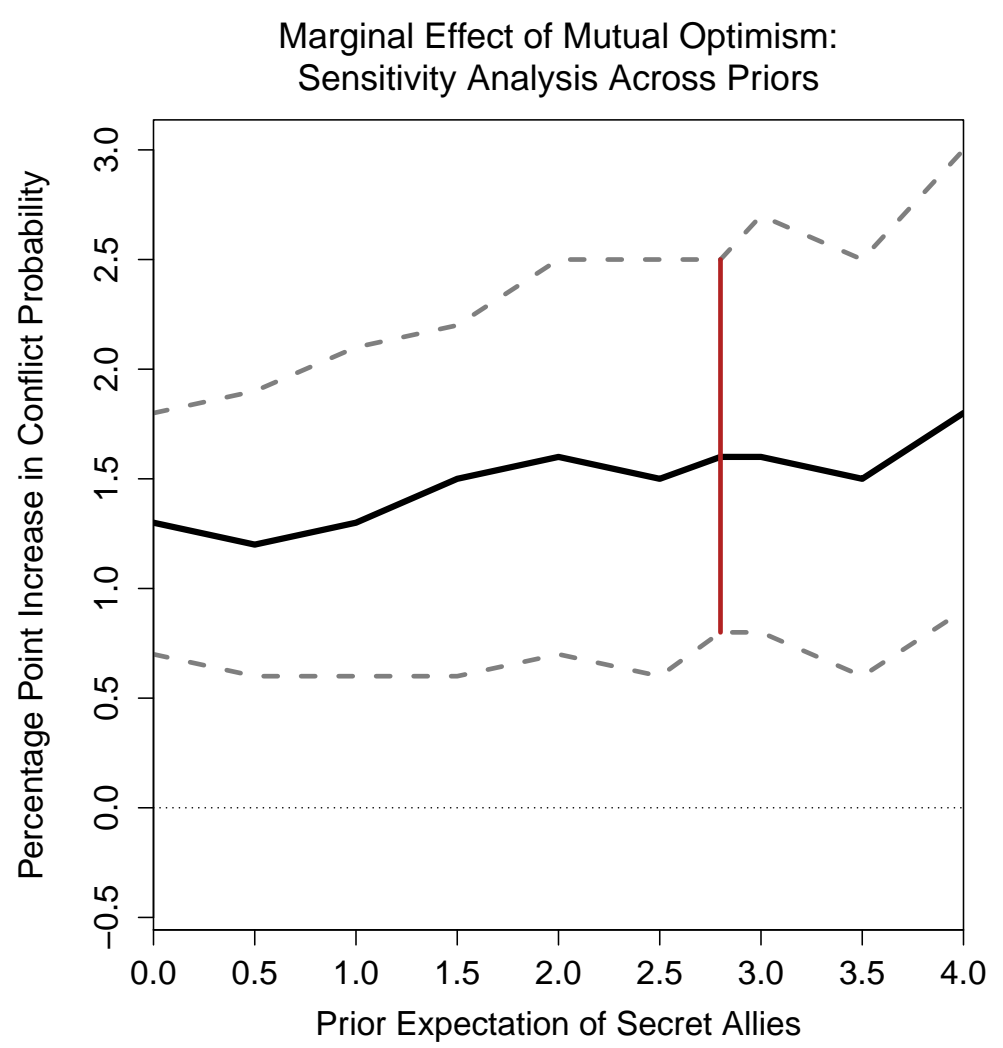

Figure 2: Marginal effect of shifting Mutual Optimism from 0 to 1 with $90 \%$ confidence bounds. Based on the dichotomous Mutual Optimism variable but with variation on the assumed prior expectation. Vertical red line indicates results at the observed prior used in Model 4.

To assess the sensitivity of results to the assumed prior expectation of what share of publicly unaligned capabilities are actually secretly aligned with the opponent, we rerun Model 4 but vary the assumed prior between $0 \%$ and $4 \%$. Recall that the observed prior is $2.8 \%$ among politically relevant dyads. We repeat the marginal effect calculation described above for each of these models

\footnotetext{
${ }^{20}$ Peace Years and its high order terms are set to 3, 9, and 27 respectively.
} 
with the results and confidence bounds plotted in Figure 2. This analysis makes it clear that the reported results are robust to using alternative priors. ${ }^{21}$

Results from specifications using the continuous measure of mutual optimism are similarly consistent with the theoretical expectations. Consider simulated quantities of interest based on the results in Model 3. With all control variables set to the median values and Mutual Optimism fixed at 0.8 , there is a $2.6 \%$ predicted probability of conflict. Shifting Mutual Optimism to 1.3, which is still well below the maximum observed value of over 1.8 , increases the probability of conflict by $0.5 \%$ points, with $90 \%$ confidence bounds that exclude the null result. That is, increasing the presence of secretly alliances induces a $20 \%$ relative increase in the probability of a MID.

There are reasons to believe the effect sizes are understated. For instance, the alliance data may be missing secret alliances that are still unknown. Conflict in such cases would be consistent with the theory but bias the results downward because they are not coded as cases of mutual optimism. Similarly, we only code alliances as secret if the entirety of the alliance was secret as indicated by ATOP. Some alliances were public but with secret provisions. We code these as public alliances. However, the secret provisions could generate mutual optimism that is not captured by the measure. Any bias from this coding choice would also deflate the results.

\section{Confounding and Robustness}

A potential critique of the empirical tests, alluded to earlier, is that states may only sign secret alliances when they already plan to initiate disputes. If this were the case, it would confound the results because an unobservable variable, intention to initiate a dispute, is causing both secret alliance formation and dispute onset. There are clear historical instances of this phenomenon occurring. For example, on the eve of the 1859 Second Italian War of Independence, Italy signed a

\footnotetext{
${ }^{21}$ The robustness of results to variation in the prior is also empirically equivalent to demonstrating robustness to (1) incorporating a possibility that allies will not honor their commitments and (2) including diminishing or increasing returns to scale for ally capability aggregation.
} 
secret offensive alliance with France to assist in its attack against Austria (Leeds et al., 2002; Ritter, 2004). If cases akin to this one are common, it would suggest that intent to attack is driving the results rather than bargaining problems arising from asymmetric information and mutual optimism. A related possibility is that states may be more likely to sign secret alliances when they fear being attacked. Below, we conduct extensive robustness tests to address these alternative hypotheses.

An initial test drops all observations in which at least one state in a dyad signed a secret alliance either during that year or in the previous two years. In the above example, this means that all dyads from 1859 to 1861 that contain either Italy or France are excluded from the regression. The intuition is that states which sign secret alliances with an intent to attack will initiate that attack quickly upon signing an alliance. If a state waits three years or more between signing secret alliances and attacking, it becomes less likely that an intent to attack drove both the alliance formation and dispute onset. Instead, such delays increase the likelihood that mutual optimism caused the dispute. ${ }^{22}$ Model 5 of Table 2 presents these results for the specification where mutual optimism is a binary measure that accounts for prior expectations. While the results are slightly attenuated compared to those reported in Model 4, mutual optimism's relationship with conflict is still substantively and statistically significant.

Additional robustness tests address the selection concern by only including secret defensive alliances in the calculation of mutual optimism. Confounding would primarily arise from offensive agreements because the attacking state wants to insure its new ally will participate in the dispute. Insuring participation is more difficult with a defensive alliance which minimizes the concern of confounding. As reported in Model 6, mutual optimism still has a positive and statistically

\footnotetext{
${ }^{22}$ We prefer this approach versus using a selection model. The necessary identification assumption for the latterthat a variable affects secret alliance signing without affecting conflict likelihood—seems implausible. Previous research finds that selection models are very sensitive to model specification and distributional assumptions (Winship and Mare, 1992; Sartori, 2003).
} 
Table 2: Robustness Tests Accounting for Selection

\begin{tabular}{|c|c|c|c|c|c|}
\hline & (5) & (6) & (7) & (8) & (9) \\
\hline & $\begin{array}{c}\text { Drop } \\
\text { Recent } \\
\text { Signers }\end{array}$ & $\begin{array}{c}\text { Only } \\
\text { Defensive } \\
\text { Alliances }\end{array}$ & $\begin{array}{c}\text { Only Dyads } \\
\text { with } \\
\text { Alliances }\end{array}$ & $\begin{array}{c}\text { Target } \\
\text { Specific } \\
\text { Measure }\end{array}$ & $\begin{array}{c}\text { Non-Target } \\
\text { Specific } \\
\text { Measure }\end{array}$ \\
\hline Mutual Optimism & $\begin{array}{l}0.38^{* *} \\
(0.19)\end{array}$ & $\begin{array}{c}0.36^{* * *} \\
(0.17)\end{array}$ & $\begin{array}{c}0.44^{* * * *} \\
(0.16)\end{array}$ & $\begin{array}{l}0.31^{*} \\
(0.17)\end{array}$ & $\begin{array}{c}0.83^{* * * *} \\
(0.20)\end{array}$ \\
\hline Relative Capabilities & $\begin{array}{c}2.25^{* * * *} \\
(0.62)\end{array}$ & $\begin{array}{c}2.25^{* * * *} \\
(0.52)\end{array}$ & $\begin{array}{c}2.71 * * * \\
(0.54)\end{array}$ & $\begin{array}{c}2.16^{* * * *} \\
(0.56)\end{array}$ & $\begin{array}{c}2.06^{* * * *} \\
(0.52)\end{array}$ \\
\hline Contiguity & $\begin{array}{c}0.76^{* * * *} \\
(0.21)\end{array}$ & $\begin{array}{c}0.83 * * * * \\
(0.18)\end{array}$ & $\begin{array}{c}0.77 * * * \\
(0.18)\end{array}$ & $\begin{array}{c}0.83^{* * * *} \\
(0.18)\end{array}$ & $\begin{array}{c}0.85^{* * * *} \\
(0.18)\end{array}$ \\
\hline Joint Democracy & $\begin{array}{l}-0.13 \\
(0.33)\end{array}$ & $\begin{array}{l}-0.09 \\
(0.26)\end{array}$ & $\begin{array}{c}0.13 \\
(0.25)\end{array}$ & $\begin{array}{l}-0.05 \\
(0.26)\end{array}$ & $\begin{array}{l}-0.22 \\
(0.26)\end{array}$ \\
\hline Alliance & $\begin{array}{c}-1.02 * * * \\
(0.28)\end{array}$ & $\begin{array}{c}-0.80 * * * * \\
(0.22)\end{array}$ & $\begin{array}{c}-0.55^{* * *} \\
(0.24)\end{array}$ & $\begin{array}{c}-0.80^{* * * *} \\
(0.23)\end{array}$ & $\begin{array}{c}-0.86 * * * * \\
(0.22)\end{array}$ \\
\hline Peace Years & $\begin{array}{c}-0.16^{* * * *} \\
(0.02)\end{array}$ & $\begin{array}{c}-0.14 * * * \\
(0.01)\end{array}$ & $\begin{array}{c}-0.13 * * * \\
(0.02)\end{array}$ & $\begin{array}{c}-0.14 * * * \\
(0.01)\end{array}$ & $\begin{array}{c}-0.13 * * * \\
(0.01)\end{array}$ \\
\hline Constant & $\begin{array}{c}-3.27 * * * \\
(0.18)\end{array}$ & $\begin{array}{c}-3.33 * * * \\
(0.16)\end{array}$ & $\begin{array}{c}-3.54 * * * \\
(0.18)\end{array}$ & $\begin{array}{c}-3.29 * * * \\
(0.16)\end{array}$ & $\begin{array}{c}-3.29 * * * \\
(0.16)\end{array}$ \\
\hline$N$ & 20,729 & 24,886 & 17,627 & 23,818 & 23,818 \\
\hline
\end{tabular}

Notes: Logistic regression with non-directed politically relevant dyad year as the unit of analysis. Standard errors in parentheses are clustered on the dyad. Results for higher order Peace Years are not shown. 
significant effect on conflict, even when calculated in a more conservative fashion that excludes secret offensive alliances.

Perhaps alliance formation, rather than secrecy itself, is a source of selection bias. Signing alliances may indicate that a state anticipates being attacked or conflict more generally. If true, then including states that have no alliances and thus do not expect to be engaged in conflict will bias the reported effect of mutual optimism upwards. Put differently, if alliance formation is itself an indicator of conflict likelihood, then states that do not sign alliances may be a poor comparison group for those that sign secret alliances. In Model 7, we exclude observations in which neither state belongs to an alliance of any sort. Mutual optimism's positive and statistically significant result still holds in this specification.

As a final robustness check, we differentiate instances of optimism based on the specific states that secret alliances target. A pre-existing intention to attack might be confounding the results if the effect of mutual optimism is due to dyads where one state has a secret alliance specifically targeting the opposing state. If results continue to hold when mutual optimism is based on alliances that do not explicitly target the opposing state in a dyad, it would alleviate concerns about selection effects. Using the coding by Johnson, Leeds and Wu (forthcoming) as a base, we construct a data set where an ally's capabilities are only included in the mutual optimism calculation if the alliance targets the opposing state in the dyad. Model 8 tests the effect of mutual optimism when calculated with only target specific capabilities included. In contrast, mutual optimism in Model 9 only includes allied capabilities that do not specifically target the opposing state.

Both specifications show a strong mutual optimism effect regardless of whether a secret alliance directly targets an opponent. In fact, the substantive and statistical effect is even stronger when only including ally capabilities not directly targeting an opponent. As discussed earlier, this latter finding could be due to multiple factors. States may anticipate support beyond the obligations noted in an alliance because of general security preference overlap between alliance members. Alternatively, the security provided by a secret alliance may allow a state to concentrate its forces 


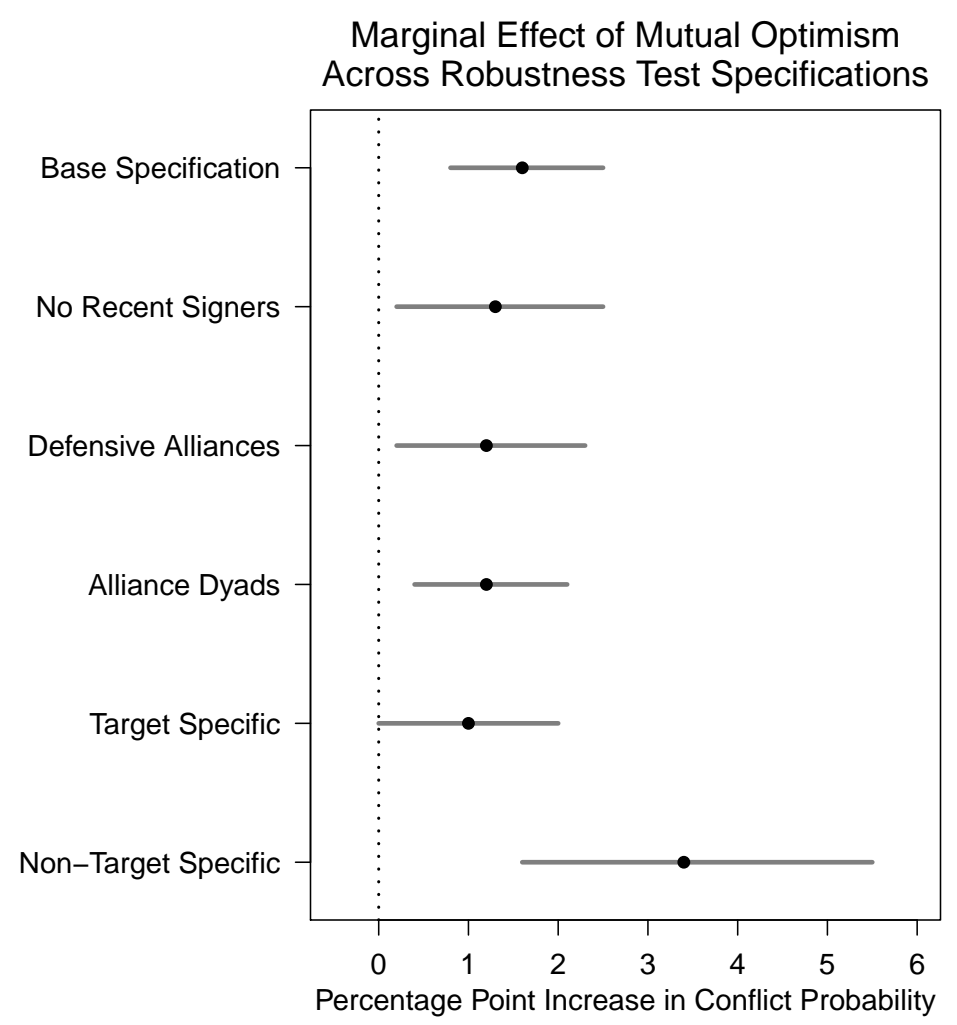

Figure 3: Marginal effect of shifting Mutual Optimism from 0 to 1 with $90 \%$ confidence bounds. Based on the dichotomous Mutual Optimism variable used across robustness specifications. From top to bottom, simulations based on Models 4 through 9.

in contested areas which grants that state a source of military power its opponents do not anticipate. Divergent prior expectations for a secret alliance may drive the larger magnitude effects in the nontarget specific model. For instance, a state specifically targeted by a bilateral alliance may suspect such an agreement exists due to generally hostile relations. As a result the targeted state would have an elevated prior expectation that either opponent has a secret ally. The higher prior expectation decreases the targeted state's own estimated probability of victory and increases the bargaining concessions it is willing to make. Note that the prior is not sufficiently high to generate peace; after all Mutual Optimism is statistically significant in the target specific model. But the prior being higher for a targeted state is consistent with a reduced substantive effect. A non-targeted state, in contrast, may be less suspecting that opponents have secret alliances. This lowers the 
non-targeted state's prior expectation, causing it to make more onerous bargaining demands which increase the probability of conflict, hence the large substantive effect. Modeling heterogeneous priors to capture this dynamic, as opposed to using a fixed rate, requires better data and theory on secret alliance formation, which we leave to future research.

Overall, the results show a strong positive and statistically significant relationship between mutual optimism and conflict across a broad range of robustness checks. Figure 3 plots the marginal effect of mutual optimism on the probability of conflict across the robustness specifications. Results in the figure help assuage concerns about confounding due to an intention to attack being a common cause of secret alliances and conflict. ${ }^{23}$ The results remain consistent with the theoretical expectation that secret alliances generate mutual optimism which undermines bargaining. That being said, the robustness tests are admittedly imperfect. Fully accounting for non-random entry into secret alliances requires a more precise theory of secret alliance formation, which is outside the scope of this study.

\section{Illustrative Case: The Bosnian Crisis of 1908}

The results reported above point to an important contributor to bargaining failures. To elaborate on the process by which mutual optimism increases the risk of conflict, we provide an overview of the militarized dispute that followed Austria-Hungary's annexation of Bosnia-Herzegovina (B-H hereafter) from Serbia. This case demonstrates the logic of mutual optimism as asymmetric information arising from Austia-Hungary's secret alliance with Germany caused a partial bargaining failure between the former and Serbia. For background, Austria-Hungary occupied and adminis-

\footnotetext{
${ }^{23}$ The supplementary files include additional robustness test specifications. In models using the continuous measure with a prior, the coefficient remains in the expected direction but falls short of conventional levels of statistical significance. Further analysis reveals the relationship between mutual optimism and conflict is strongest in the former's primary range of interest around a value of one. The lack of statistical significance is attributable to a weaker relationship in the tails of the mutual optimism measure where conflict is already either very unlikely or likely to occur.
} 
tered B-H for thirty years as stipulated by the 1878 Treaty of Berlin (Schmitt, 1930). From the Austrian perspective, annexation provided legal recognition of a de facto reality.

Why did annexation spark an international crisis? Importantly, Austrian power was bolstered by anticipated support from Germany arising from multiple secret alliances. The two shared three secret agreements at the time, including the Triple Alliance. The Dual Alliance obligated the two parties to assist one another in case either is engaged in a military conflict with Russia. Moreover, all of these alliances were signed many years before the Bosnian Crisis which reduces concerns of confounding due to an pre-existing intention to attack. ${ }^{24}$

Beyond treaty stipulations, the diplomatic record indicates that Austrian behavior was influenced by an expectation of German support. Austria-Hungary's Foreign Minister Count Alois Lexa von Aehrenthal notified the major powers of Europe of the planned annexation weeks before it occurred, even obtaining secret approval from Russian Foreign Minister Izvolski in exchange for concessions in the Straits (Joll, 1992, p. 57). Aehrenthal anticipated steadfast German support (Bridge, 1972, p. 302). After initial consternation over the hastiness of annexation (Bridge, 1972, p. 305), German Chancellor Bulow argued to Wilhelm II that maintaing the alliance with Austria-Hungary was the most important diplomatic concern and assured Vienna that "it is for us an act of self-evident loyalty to hold fast to the alliance with Austria-Hungary" (Schmitt, 1931a, p. 655). ${ }^{25}$ This expectation of German support was bolstered by January assurances from Moltke, with Wilhelm II's knowledge, that "Austrian invasion of Serbia could bring about an eventual ac-

\footnotetext{
${ }^{24}$ Details of the agreements are in ATOP alliance code sheets for alliances 1350 (phase 3) and 1335 respectively. Portions of the Triple Alliance obligate the sides to militarily assist each other in an offensive war, though these clauses do not strictly pertain to actions in the Balkans. The secret Dual Alliance concerning a war against Russia is defensive in nature (Leeds et al., 2002). However, it clearly influenced Austrian assessments and German assurances (Bridge, 1990, p. 292).

${ }^{25}$ In accordance with Article VII of the Triple Alliance, Aehrenthal sought Italian approval for this change to the Balkans status quo and received tepid but satisfactory signals that Italy would at least not oppose the annexation (Schmitt, 1930; Leeds et al., 2002).
} 
tive intervention of Russia. This would create the casus foederis for Germany" (Schmitt, 1932, p. 656).

Serbia's reaction to the annexation was expectedly negative. Serbia mobilized its forces, calling up reserves to triple the strength of its military personnel. Austria-Hungary conducted its own phased mobilization in response (Stevenson, 1997). Crucially, Serbia likely anticipated that a war would be between itself, with Russian support, and only Austria-Hungary. Both Izvolski and the Serbian Foreign Minister even sought German backing when soliciting international support for the Serbian position, apparently unaware of Germany's professed backing of Austrian actions (Schmitt, 1931b, p. 166). Serbia and Austria-Hungary's divergent expectations for German participation were the source of mutual optimism in this crisis.

Izvolski's October visits to, and communications with, London, Paris, and Berlin (Sabrosky, 1975) convinced him that Germany would support Austria-Hungary in a conflict (Schmitt, 1931b, p. 167). Izvolski offered to assist Serbia in future efforts seeking renumeration but cautioned against war. He subsequently learned from his General Staff that a "a conflict with AustriaHungary alone would not be without chance of success, but that one with both the western neighbours must be given up from the start" (Schmitt, 1932, p. 645). Moreover, Aehrenthal threatened to publicly reveal Izvolski's earlier private commitments at Buchlau to abandon Serbian claims for compensation in the event of annexation (Bridge, 1990, p. 291). Izvolski finally capitulated due to (1) the increasingly apparent German military backing for Austria-Hungary, (2) Germany's unwillingness to restrain Austrian actions (Bridge, 1990, p. 295), (3) Russia's poor military prospects in the event of German entry into war, and (4) Izvolski's fear of having past secret concessions revealed. Cornered, Izvolski convinced Serbia that annexation was a fait accompli which military threats could not alter.

While the Bosnian Crisis stopped short of war, it was a militarized dispute due to the threats and shows of force undertaken by both Austria-Hungary and Serbia. Divergent estimates of their respective strengths caused the crisis to escalate and persist. In the terms of formal models of mutual 
optimism, Serbia had limited information about Austrian capabilities and believed it was facing a weak type when Austria-Hungary was actually a strong type. These contrasting estimates of the dyadic power balance undermined bargaining until Russia urged Serbia to abandon its claims.

\section{Conclusion}

Scholars regard mutual optimism as one of the primary paths to war. Despite its theoretical prominence there are no prior systematic empirical evaluations of whether contradictory perceptions of bargaining power increases the risk of war. We fill this lacuna with a new extension to the logic of mutual optimism that recognizes divergent views of the power balance can arise due to private information about external, as opposed to internal, military capabilities. Secret alliances by construction generate information asymmetries. In theory, bargaining breakdowns could occur when a state's secret allies are more numerous or stronger than an opponent anticipates. Extensive empirical tests show support for this hypothesis, which in turn supports the broader argument concerning mutual optimism as a cause of conflict.

The apparent decline of secret alliances in international politics does not limit the relevance of the paper's findings. Contemporary secret alliances may simply still be unrevealed or take the form of informal secret agreements. More broadly, divergent expectations about third party behavior, as observed before the Gulf War, remains a feature of international politics. The many ways that external sources of power can cause contrasting capability estimates highlight the external validity and importance of our results.

For policy, the results highlight the dangers of secret agreements and suggest that transparent deterrent postures from public alliances are more likely to yield peaceful resolutions. This contention echoes the first of Woodrow Wilson's Fourteen Points which prescribes "Open covenants of peace, openly arrived at, after which there shall be no private international understandings of any kind but diplomacy shall proceed always frankly and in the public view" (Wilson, 1918). 
Do our findings imply that mutual optimism arising from internal sources of power is also an important cause of conflict? Mutual optimism due to private information about one's own military capabilities is the primary conception in the extant literature. Though our specifications do not address this form of mutual optimism, the logical underpinnings are the same. Future research could provide measures of internal sources of optimism. Our findings indicate that such efforts would be fruitful as we conclude that mutual optimism is not only a logically tenable cause of conflict, but it is also an empirically important one. 


\section{References}

Bas, Muhammet A. 2012. "Measuring Uncertainty in International Relations: Heteroskedastic Strategic Models." Conflict Management and Peace Science .

Bennett, D. Scott and Allan C. Stam. 2004. The Behavioral Origins of War. Ann Arbor, MI: University of Michigan Press.

Benson, Brett V. 2011. "Unpacking Alliances: Deterrent and Compellent Alliances and Their Relationship with Conflict, 1816-2000.” Journal of Politics 73(4):1111-1127.

Benson, Brett V., Adam Meirowitz and Kristopher W. Ramsay. 2014. "Inducing Deterrence through Moral Hazard in Alliance Contracts.” Journal of Conflict Resolution 58(2):307-335.

Blainey, Geoffrey. 1988. The Causes of War. London, Macmillan.

Bridge, F. R. 1972. From Sadowa to Sarajevo: The Foreign Policy of Austria-Hungary, 1866-1914. London: Routledge and Kegan Paul.

Bridge, F. R. 1990. The Hapsburg Monarchy among the Great Powers, 1815-1918. Oxford, UK: Berg Publishers Limited.

Carter, David B. and Curtis S. Signorino. 2010. "Back to the Future: Modeling Time Dependence in Binary Data.” Political Analysis 18:271-292.

Childs, Timothy W. 1990. Italo-Turkish Diplomacy and the War over Libya, 1911-1912. New York: Brill.

Colaresi, Michael. 2014. Democracy Declassified: The Secrecy Dilemma and Oversight in Liberal States. Oxford University Press.

Fang, Songying, Jesse C. Johnson and Brett Ashley Leeds. 2014. "To Concede or To Resist? The Restraining Effect of Military Alliances.” International Organization 68(4):775-809. 
Fearon, James D. 1994. "Political Audiences and the Escalation of International Disputes.” The American Political Science Review 88(3).

Fearon, James D. 1995. “Rationalist Explanations for War.” International Organization 49(3):379_ 414.

Fearon, James D. 1997. “Signaling Foreign Policy Interests: Tying Hands versus Sinking Costs.” Journal of Conflict Resolution 41(1):68-90.

Fey, Mark and Kristopher W. Ramsay. 2007. "Mutual Optimism and War." American Journal of Political Science 51(4):738-754.

Fey, Mark and Kristopher W. Ramsay. 2012. "Mutual Optimism and Choosing to Fight.” Unpublished typescript.

Freedman, Lawrence and Efraim Karsh. 1997. The Gulf Conflict 1990-1991: Diplomacy and War in the New World Order. Princeton, NJ: Princeton University Press.

Gartzke, Erik and Kristian S. Gleditsch. 2004. "Why Democracies May Actually Be Less Reliable Allies." American Journal of Political Science 48(4):775-95.

Ghosn, Faten, Glenn Palmer and Stuart Bremer. 2004. “The MID3 Data Set, 1993-2001: Procedures, Coding Rules, and Description.” Conflict Management and Peace Science 21(2):133-54.

Gibler, Douglas and Meredith Sarkees. 2002. "Coding Manual for v3.0 of the Correlates of War Formal Interstate Alliance Data set, 1816-2000.” Typescript.

Heikal, Mohamed. 1992. Illusions of Triumph: An Arab View of the Gulf War. Harper Collins Publishers.

Hernan, Miguel A. and James M. Robins. 2006. "Estimating Causal Effects from Epidemiological Data.” Journal of Epidemiology and Community Health 60:578-586. 
Jervis, Robert. 1976. Perception and Misperception in International Politics. Princeton, N.J.: Princeton University Press.

Johnson, Dominic. 2004. Overconfidence and War: The Havoc and Glory of Positive Illusions. Cambridge, MA: Harvard University Press.

Johnson, Jesse C., Brett Ashley Leeds and Ahra Wu. forthcoming. "Capability, Credibility, and Extended General Deterrence.” International Interactions .

Joll, James. 1992. The Origins of the First World War. Second edition ed. New York, NY: Longman Inc.

Kahneman, Daniel and Jonathan Renshon. 2007. "Why Hawks Win.” Foreign Policy 158:34-38.

Khadduri, Majid and Edmund Ghareeb. 1997. War in the Gulf, 1990-1991: The Iraq-Kuwait Conflict and its Implications. Oxford University Press.

King, Gary, Michael Tomz and Jason Wittenberg. 2000. "Making the Most of Statistical Analyses: Improving Interpretation and Presentation.” American Journal of Political Science 44(2):34761.

Langlois, Catherine C. 2012. "Power and Deterrence in Alliance Relationships." Conflict Management and Peace Science 29(2):148-169.

Lebow, Richard Ned. 1981. Between Peace and War: The Nature of International Crises. Baltimore, MD: The Johns Hopkins University Press.

Leeds, Brett Ashley. 2003a. "Alliance Reliability in Times of War: Explaining State Decisions to Violate Treaties." International Organization 57(4):801-827.

Leeds, Brett Ashley. 2003b. "Do Alliances Deter Aggression? The Influence of Military Alliances on the Initiation of Militarized Interstate Disputes." American Journal of Political Science 47(3):427-439. 
Leeds, Brett Ashley, Andrew G. Long and Sara McLaughlin Mitchell. 2000. "Reevaluating Alliance Reliability: Specific Threats, Specific Promises.” Journal of Conflict Resolution 44(5):686-699.

Leeds, Brett Ashley and Burcu Savun. 2007. “Terminating Alliances: Why Do States Abrogate Agreements?" Journal of Politics 69(4):1118-1132.

Leeds, Brett Ashley, Jeffrey M. Ritter, Sara McLaughlin Mitchell and Andrew G. Long. 2002. “Alliance Treaty Obligations and Provisions.” International Interactions 28(2):237-260.

Leeds, Brett Ashley, Michaela Mattes and Jeremy S. Vogel. 2009. "Interests, Institutions, and the Reliability of International Commitments." American Journal of Political Science 53(2):461476.

Marshall, Monty G. and Keith Jaggers. 2002. Polity IV Dataset [Computer file]. College Park, MD: University of Maryland.

Mattes, Michaela. 2012. "Reputation, Symmetry, and Alliance Design.” International Organization 66:679-707.

Morrow, James D. 1989. “Capabilities, Uncertainty, and Resolve: A Limited Information Model of Crisis Bargaining." American Journal of Political Science 33(4):941-972.

Morrow, James D. 2000. “Alliances: Why Write Them Down?” Annual Review of Political Science $3: 63-83$.

Oneal, John R., Bruce Russett and Michael L. Berbaum. 2003. "Causes of Peace: Democracy, Interdependence, and International Organizations, 1885-1992.” International Studies Quarterly 47(3):371-393.

Powell, Robert. 1999. In the Shadow of Power: States and Strategies in International Politics. Princeton, N.J.: Princeton University Press. 
Reed, William. 2003. "Information, Power, and War." American Political Science Review 97(4):633-41.

Rider, Toby J. 2013. "Uncertainty, Salient Stakes, and the Causes of Conventional Arms Races.” International Studies Quarterly 57(3):580-591.

Ritter, Jeffrey M. 2004. Silent Partners and Other Essays on Alliance Politics PhD thesis Harvard University.

Sabrosky, Alan Ned. 1975. "From Bosnia to Sarajevo: A Comparative Discussion of Interstate Crises.” Journal of Conflict Resolution 19(1):3-24.

Sartori, Anne E. 2002. "The Might of the Pen: A Reputational Theory of Communication in International Disputes." International Organization 56(1):123-151.

Sartori, Anne E. 2003. "An Estimator for Some Binary-Outcome Selection Models Without Exclusion Restrictions.” Political Analysis 11(2):111-138.

Schmitt, Bernadotte. 1930. "The Bosnian Annexation Crisis (I).” The Slavonic and East European Review 9(26):312-334.

Schmitt, Bernadotte. 1931a. "The Bosnian Annexation Crisis (II)." The Slavonic and East European Review 9(27):650-661.

Schmitt, Bernadotte. 1931b. "The Bosnian Annexation Crisis (III)." The Slavonic and East European Review 10(28):161-171.

Schmitt, Bernadotte. 1932. "The Bosnian Annexation Crisis (V)." The Slavonic and East European Review 10(30):641-657.

Simmons, Beth. 2010. “Treaty Compliance and Violation.” Annual Review of Political Science 13:273-296. 
Singer, J. David, Stuart Bremer and John Stuckey. 1972. Capability Distribution, Uncertainty, and Major Power War, 1820-1965. In Peace, War, and Numbers, ed. Bruce Russett. Sage: Beverly Hills.

Slantchev, Branislav L. 2003. “The Principle of Convergence in Wartime Negotiations.” American Political Science Review 97(4):621-632.

Slantchev, Branislav L. 2004. "How Initiators End Their War: The Duration of Warfare and the Terms of Peace.” American Journal of Political Science 48(4):813-829.

Slantchev, Branislav L. 2010. “Feigning Weakness.” International Organization 64(3):357-388.

Slantchev, Branislav L. and Ahmer Tarar. 2011. "Mutual Optimism as a Rationalis Explanation for War." American Journal of Political Science 55(1):135-148.

Smith, Alastair. 1995. “Alliance Formation and War.” International Studies Quarterly 39(4):405425.

Smith, Alastair and Allan C. Stam. 2004. "Bargaining and the Nature of War." Journal of Conflict Resolution 48(6):783-813.

Snyder, Glenn H. 1984. "The Security Dilemma in Alliance Politics.” World Politics 36(4):461495.

Sobek, David and Joe Clare. 2013. "Me, Myself, and Allies: Understanding the External Sources of Power.' Journal of Peace Research 50(4):469-478.

Starr, Harvey and G. Dale Thomas. 2005. "The Nature of Borders and International Conflict: Revisiting Hypotheses on Territory.” International Studies Quarterly 49(1):123-139.

Stevenson, David. 1997. "Militarization and Diplomacy in Europe before 1914." International Security 22(1):125-161. 
Van Evera, Stephen. 1999. Causes of War: Power and the Roots of Conflict. Ithaca, NY: Cornell University Press.

Wagner, Harrison R. 1994. "Peace, War, and the Balance of Power." American Political Science Review 88(3):593-607.

Weeks, Jessica L. 2008. “Autocratic Audience Costs: Regime Type and Signaling Resolve.” International Organization 62:35-64.

Werner, Suzanne. 2000. "Deterring Intervention: The Stakes of War and Third-Party Involvement." American Journal of Political Science 44(4):720-732.

Wilson, Woodrow. 1918. "Fourteen Points.” Lillian Goldman Library, Yale Law School [Accessed $10 / 15 / 14]$.

Winship, Christopher and Robert D. Mare. 1992. "Models for Sample Selection Bias.” Annual Review of Sociology 18:327-350.

Wolford, Scott. 2007. "The Turnover Trap: New Leaders, Reputation, and International Conflict." American Journal of Political Science 51(4):772-788.

Yarhi-Milo, Keren. 2013. “Tying Hands Behind Closed Doors: The Logic and Practice of Secret Reassurance.” Security Studies 22(3):405-435.

Yuen, Amy. 2009. "Target Concessions in the Shadow of Intervention." Journal of Conflict Resolution 53(5):745-773. 